\title{
A Rapid and Convenient Method for Determining the Dry Weight Content of Bacteria Which Show a Tendency to Form Large Aggregates
}

\author{
By D. A. STORMONTH AND G. COLEMAN \\ Department of Biochemistry, University of Nottingham, Nottingham, $N_{7} 2 R D$
}

(Accepted for publication 9 February 1972)

Bacillus amyloliquefaciens readily forms large aggregates (Welker \& Campbell, 1967) and dry weights determined indirectly by bacterial counts, turbidimetry or nephelometry (Mallette, I969) are not satisfactory and consequently the direct determination of dry weight has always been used (Coleman \& Elliott, I962). We have now developed a rapid turbidimetric technique for this determination which gives comparable results to those obtained by the direct method.

\section{METHOD}

Samples of bacterial culture, usually in the range 2 to $5 \mathrm{ml}$, were centrifuged for $2 \mathrm{~min}$ at $2500 \mathrm{~g}$ and resuspended to the original volume in distilled water. The resulting suspension was then treated with an ultrasonic disintegrator ( $100 \mathrm{~W}, 20 \mathrm{kHz}$; M.S.E. Ltd, Crawley, Sussex) for I min. A sample, usually I $\mathrm{ml}$, of the disrupted preparation was then diluted with distilled water to $2 \mathrm{ml}$ and $2 \mathrm{ml}$ of $10 \%(\mathrm{w} / \mathrm{v})$ trichloroacetic acid was added. After thorough mixing the extinction of the resulting turbid suspension was measured at $600 \mathrm{~nm}$ in a cuvette of I cm light path by means of a Unicam SP 500 spectrophotometer.

\section{RESULTS AND DISCUSSION}

When applying the developed technique to different amounts of the same exponential phase culture of Bacillus amyloliquefaciens, in which aggregation of the bacteria was negligible, the relationship is linear up to an extinction of at least 0.8 and meaningful readings are obtained with very small amounts of bacteria in suspension. Bacterial dry weights, determined directly, are directly proportional to the extinction readings, obtained by the present technique, of a series of samples from a culture of $B$. amyloliquefaciens taken at different times throughout the growth cycle (Fig. I). The direct proportionality of the two sets of results extends through the exponential phase (up to about $1.5 \mathrm{mg}$ dry wt bacteria/ml), when there is no significant tendency for the bacteria to aggregate, into the post-exponential phase and to the end of the growth cycle when the tendency for clumping of the bacteria is very pronounced.

In addition to simplicity and speed the technique has the advantage of being applicable to the organism at different stages of growth and in different states of aggregation. Only small amounts of bacterial suspension are required for measurements compared with the direct method which requires $40 \mathrm{ml}$ of culture for a single determination. The method has been applied successfully to other bacteria including those which show no tendency to clump. 


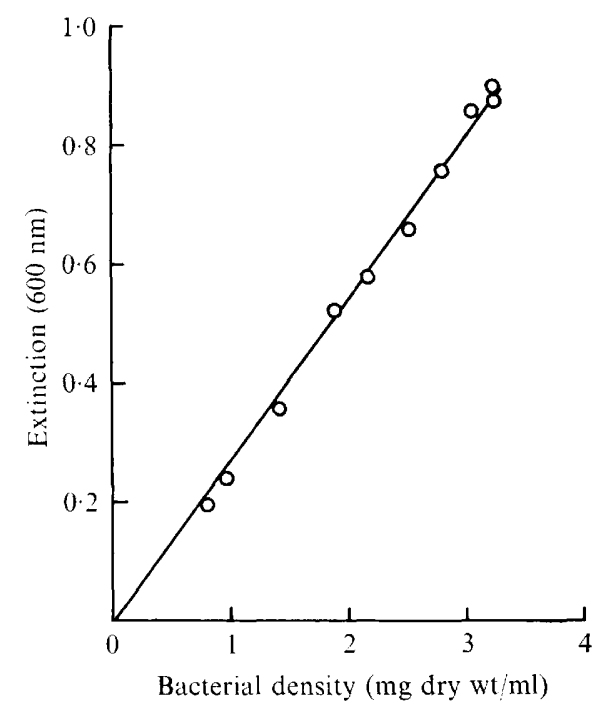

Fig. I. The relationship between extinction and bacterial density of samples of culture taken at different stages during the growth cycle. Bacillus amyloliquefaciens was cultured in a defined medium (Coleman \& Grant, 1966) and treated as described in the text.

D.A.S. thanks the S.R.C. for a Research Studentship.

\section{REFERENCES}

Coleman, G. \& Elliott, W. H. (1962). Studies on $\alpha$-amylase formation by Bacillus subtilis. Biochemical Journal 83, 256-263.

Coleman, G. \& Grant, M. A. (1966). Characteristics of $\alpha$-amylase formation by Bacillus subtilis. Nature, London 21I, 306-307.

MALLeTTE, M. F. (1969). Evaluation of growth by physical and chemical means. In Methods in Microbiology, vol. I, pp. 52I-566. Edited by J. R. Norris \& D. W. Ribbons. London and New York: Academic Press.

WeLKeR, N. E. \& CAMPBell, L. L. (1967). Unrelatedness of Bacillus amyloliquefaciens and Bacillus subtilis. Journal of Bacteriology 94, II 24-1 130. 